\title{
Effect of Whey Protein Concentrate on Postprandial Changes in Plasma Concentrations of Retinol and Triglyceride in Preruminant Calves
}

\author{
Shiro KUSHIBIKI, Hiroyuki SHINGU, \\ Akira WATANABE and Koichi HODATE \\ Tohoku National Agricultural Experimental Station, \\ Morioka-shi 020-01
}

(Received July 11, 1997)

\begin{abstract}
Four Holstein male calves were used to study the effect of whey protein concentrate (WPC) on postprandial changes in plasma retinol and triglyceride concentrations. Suckling tests were conducted on the calves using Holstein cow whole milk mixed with Vitamin A acetate, with or without WPC, at weekly intervals from immediately after birth to 6 weeks of age. A catheter was inserted into a jugular vein and blood samples were taken from just until $8 \mathrm{~h}$ after the feeding of the whole milk at $0800 \mathrm{~h}$. Plasma retinol and triglyceride concentrations were determined by HPLC and enzymatic methods, respectively. The concentrations of plasma retinol increased gradually following the feeding of both milk. However, no significant effect of WPC on plasma retinol was found. On the other hand, the plasma concentration of triglyceride in the calves fed the milk with WPC were significantly higher than that of the calves fed the milk without WPC 8 $\mathrm{h}$ after the feeding. This suggests that WPC participates in milk fatty acid metabolism and not in retinol transport in preruminant calves.
\end{abstract}

Anim. Sci. Technol. (Jpn.) 68 (12) : 1137-1140, 1997

Key words : Whey protein concentrate, Preruminant calves, Plasma retinol, Plasma triglyceride

The physiochemical properties of whey protein fractions have recently been clarified using whey protein concentrate $(\mathrm{WPC})^{2,10}$. For example, $\beta$-lactoglobulin $(\beta-L G), \quad \alpha-$ lactalbumin $(\alpha-\mathrm{L} \Lambda)$ and serum albumin (BSA) bind hydrophobic molecules in vitro ${ }^{6,9}$. However, the biological function of $\beta-L G$, a major whey protein of ruminant milk, has not yet been satisfactorily resolved despite intensive research ${ }^{8)}$. It is considered likely that this protein participates in the lipid metabolism of milk in preruminant calves because $\beta$-LG binds retinol and fatty acids in vitro ${ }^{9)}$. Therefore, in this study, we examined the effect of WPC on postprandial changes of plasma retinol and triglyceride in preruminant calves.

子牛の哺乳後の血獎レチノールおよび中性脂肪濃度に及代す乳清タンパク質濃縮物（WPC）の影響：櫛引史郎・ 新宮博行・渡辺 彰・甫立孝一（農林水産省東北農業試験場，盛岡市 020-01） 


\section{Materials and Methods}

Four male Holstein calves were used from immediately after birth to 6 weeks of age. The calves were given dam's milk for the first 2 days after birth. During the experimental period, the calves were fed Holstein whole milk twice daily at 0800 and $1600 \mathrm{~h}$. The daily volume of milk was fixed at $10 \%$ (morning, $4 \%$ ; evening, $6 \%$ ) of the body weight of the calves at the beginning of every week of the experimental period. The experimental period was divided into two equal periods, a preruminant phase (1-3 weeks) and a transitional phase (4-6 weeks $)^{11}$. At the beginning of each phase, the calves weighed $49.8 \pm 4.1$ and $58.3 \pm 3.9 \mathrm{~kg}$, respectively.

The suckling tests using the whole milk with WPC were performed once a week during the experimental period on each calf. As a control, the suckling tests using the milk without WPC were performed in the same way. The suckling tests using the milk with WPC wcre carried out 3 days after the control tests. Vitamin A acetate $(500,000 \mathrm{IU})$ was mixed with the whole milk used for the suckling test. The addition of WPC powder (whey protein, 34\%; $\beta$-LG, $17.3 \%$; lipid, $1 \%$; lactose, $45 \%$ ) was adjusted to $3.6 \mathrm{wt} \%$ of the morning milk. The whey protein content of whole milk with WPC added is equivalent to that of a Holstein cow's milk at 1 or 2 days postpartum ${ }^{4}$. For the suckling test, milk, corresponding to $4 \%$ of body weight, was fed by nipple bucket to each calf at $0800 \mathrm{~h}$. A catheter was inserted into one of the external jugular veins $30 \mathrm{~min}$ before the morning meal.

Blood samples $(6 \mathrm{~m} l)$ were collected and placed into heparinized test tubes just before $(0$ $\mathrm{h}$ ) and at $1 \mathrm{~h}$ intervals until $8 \mathrm{~h}$ following the morning meal, and were centrifuged immediately. The plasma was stored at $-20^{\circ} \mathrm{C}$ for subsequent analysis. Plasma retinol was determined by HPLC using a method described elsewhere ${ }^{5)}$. Plasma triglyceride was assayed using a commercially available kit (Wako Pure Chemical Ind., Ltd, Osaka) by automatic analyzer (HIT $\Lambda \mathrm{CHI} 7070)$.

Student's $t$-tests were used to assess the sig. nificance of differences in the data.

\section{Results and Discussion}

In both the preruminant and transitional phases, the plasma retinol concentrations of the calves fed either diet increased gradually after the morning meal (Fig. 1). However, the postprandial changes of plasma retinol in both phases were not significantly affected by whole milk supplemented with WPC.

Postprandial changes of plasma triglyceride concentrations in the calves fed both diets demonstrated a similar pattern until $6 \mathrm{~h}$ after the morning meal in the preruminant phase and until $7 \mathrm{~h}$ in the transitional phase (Fig. 2). In both phases, the concentration of plasma triglyceride in the calves fed the whole milk without WPC reached a maximum value at $7 \mathrm{~h}$ after feeding and then dccreased rapidly at $8 \mathrm{~h}$ postfeeding. In the calves fed the whole milk with WPC in the preruminant phase, the concentration of triglyceride continued to increase from $7(34.3 \mathrm{mg} / \mathrm{d} l$; mean) to $8 \mathrm{~h}(38.2 \mathrm{mg} / \mathrm{d} l)$ postfeeding. These values were significantly higher $(\mathrm{P}<0.05-0.001)$ compared with the corresponding values $(23.9$ and $15.2 \mathrm{mg} / \mathrm{d} l$ ) for the calves fed the whole milk without WPC. In the transitional phase, the concentration (38.6 $\mathrm{mg} / \mathrm{d} l$ ) of plasma triglyceride $8 \mathrm{~h}$ after feeding the milk with WPC was higher than that (23.6 $\mathrm{mg} / \mathrm{d} l$ ) of the calves fed the milk without WPC $(\mathrm{P}<0.05)$. Thus, the concentrations of plasma triglyceride were significantly affected by feeding whole milk with WPC.

The present study indicates that WPC accelarates the absorption of triglyceride but not retinol in preruminant calves. This finding, so far as we know, has not previously been reported for calves in vivo. It has been assumed that the biological role of $\beta-L G$ and BSA is to promote the transport of milk retinol and 


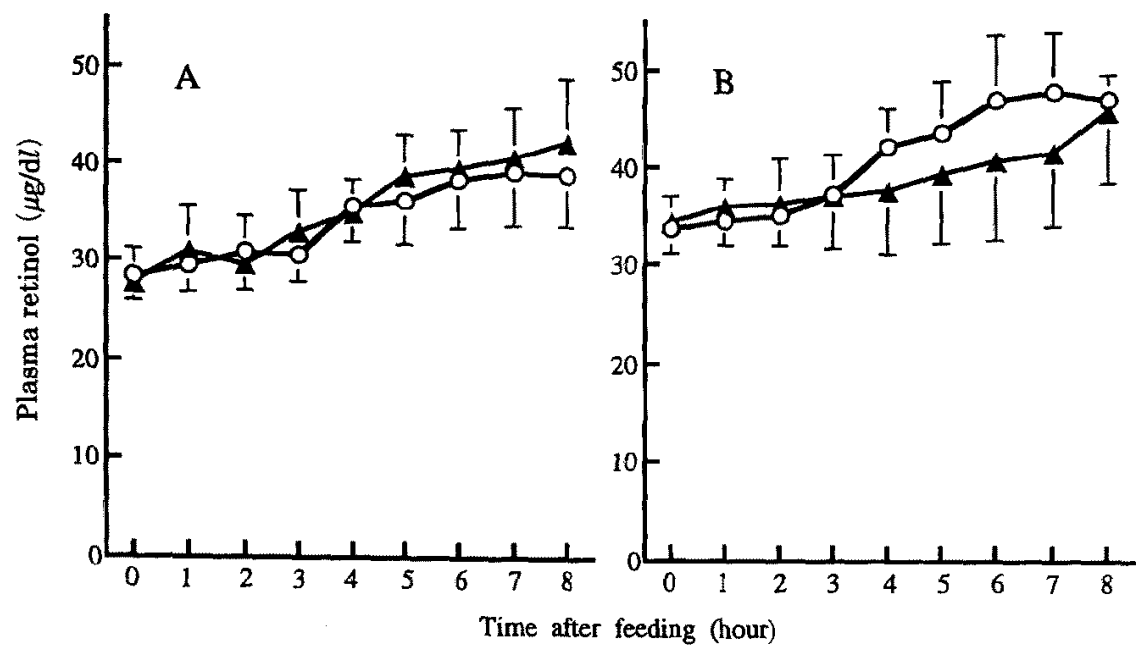

Fig. 1. Postprandial changes in plasma retinol concentrations in calves fed whole milk with (A) or without $(O)$ WPC in the preruminant phase (1-3 weeks of age ; A) and in the transitional phase (4-6 weeks of age ; B). Each point and bar represents the mean \pm S.E. for $12(4 \times 3)$ calves.

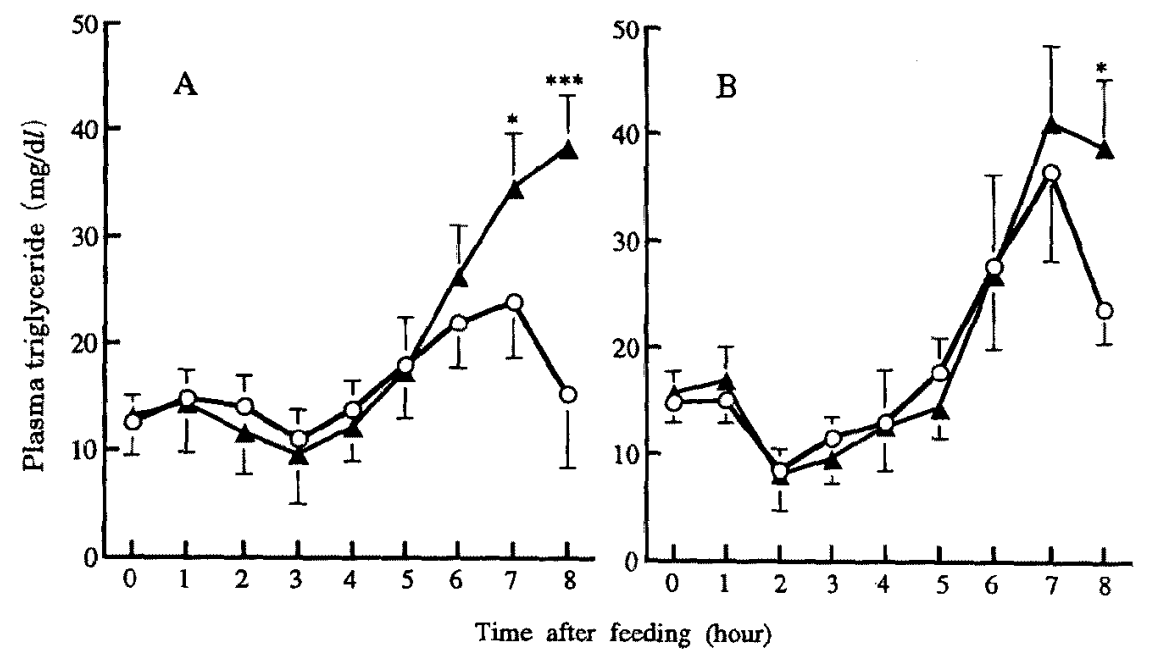

Fig. 2. Postprandial changes in plasma triglyceride concentrations in calves fed whole milk with $(\mathbf{\Delta})$ or without $(O)$ WPC in the preruminant phase (1-3 weeks of age; A) and in the transitional phase (4-6 weeks of age; B). Each point and bar represents the mean \pm S.E. for 12 $(4 \times 3)$ calves. Asterisks indicate the level of statistical difference $;{ }^{*} \mathrm{P}<0.05,{ }^{* * *} \mathrm{P}<0.001$ as compared with the corresponding values for the calves fed the whole milk without WPC.

fatty acids from the intestine of preruminant animals, and that these proteins enhance the digestion of milk lipids ${ }^{8)}$. Because $\beta-\mathrm{LG}$ is a major whey protein in the milk of ruminant species and is a member of the lipid-binding protein family ${ }^{1 /}$ as well as having a significant correlation to the functional properties of $\mathrm{WPC}^{3)}$, this protein seems to mainly participate in the transport of milk lipids in preruminant calves $^{2)}$. In this study, it is possible that the 
continued increase in the concentration of plasma triglyceride in the calves fed the whole milk with WPC may be due to the higher $\beta-\mathrm{LG}$ content of the milk. It has been reported recently that bovine $\beta$-LG increases the activity of ruminant pregastric lipase ${ }^{7)}$. Pregastric lipase activity is high in newborn animals and decreases markedly in older animals ${ }^{8)}$. Hence, it is possible that the functional properties of WPC markedly affected the concentration of plasma triglyceride in the calves in the preruminant phase.

On the other hand, the change in plasma retinol concentration following feeding was not affected by WPC under the present experimental conditions. Because retinol competes with fatty acids in binding to $\beta$-LG in vitro ${ }^{9}$, it was presumed that the addition of $\beta-\mathrm{LG}$ to whole milk may result in an acceleration in retinol transport. The physiological action of WPC on retinol transport in vivo in preruminant calves remains to be elucidated.

In conclusion, the present study clearly indicates that the plasma triglyceride concentration in preruminant calves is increased significantly by WPC. These results support the hypothesis for a biological role for ruminant $\beta-\mathrm{LG}$, which may be more closely related to milk fatty acid metabolism than to retinol transport ${ }^{7)}$.

\section{Acknowledgements}

The authors are grateful to Dr. Toshihiko Ishikawa (Central Research Department of Nippon Formula Feed Mfg. Co., Ltd.) for his helpful suggestions.

We are also grateful to Dr. M.T. Rose (National Institute of Animal Industry) for his help with the English language.

\section{References}

1) Banaszak L, Winter $N, X u$ Z, Bernlohr DA, Cowan S, Jones AT. Lipid-binding proteins : a family of fatty acid and retinoid transport proteins. Adv. Protein Chem., 45 : 89-151. 1994.

2) Creamer LK, MacGibbon KH. Some recent advances in the basic chemistry of milk proteins and lipids. Int. Dairy Journal, 6 : 539-568. 1996.

3) Dominic WSW, Wayne MC, Attila EP. Structures and Functionalities of milk proteins. Criti. Rev. Food Sci. and Nutr., $36: 807-844$. 1996.

4) Hodate $K$, Johke $T$, Ohmori $S$, Irie $T$, Mori $M$, Ikeda $T$. Changes of the concentration of the milk serum proteins in dairy cows after parturition. Jpn. J. Zootech. Sci., 49 : 588-593. 1978.

5) McCormick AM, Joseph L, Napoli, Deluca HF. High-pressure liquid chromatographic resolution of vitamin A compounds. Anal. Biochem., $86: 25-33.1978$.

6) Perez MD, Villegas CD, Sanchez L, Aranda P, Ena JM, Calvo M. Interaction of fatty acids with $\beta$-lactoglobulin and albumin from ruminant milk. J. Biochem., 106 : 1094-1097. 1989.

7) Perez MD, Sanchez L, Aranda P, Ena JM, Oria R, Calvo M. Effect of $\beta$-lactoglobulin on the activity of pregastric lipase. A possible role for this protein in ruminant milk. Biochim. Biophys. Acta., 1123: 151-155. 1992.

8) Perez MD, Calvo M. Interaction of $\beta$ lactoglobulin with retinol and fatty acids and its role as a possible biological function for this protein : a review. J. Dairy Sci., $78: 978-988$. 1995.

9) Puyol P, Perez MD, Ena JM, Calvo M. Interaction of bovine $\beta$-lactoglobul and other bovine and human whey proteins with retinol and fatty acids. Agric. Biol. Chem., $55: 2515-2520$. 1991.

10) Tadeusz S, Carl-Ludwig R. Whey and Whey Utilization. 2nd ed. 44-135. Verlag Th. Mann, Gelsenkirchen-Buer. Germany. 1990.

11) Tomkins $T$, Jaster $E H$. Preruminant calf nutrition. Vet. Clin. of North America : Food. Anim. Practice., 7 : 557-576. 1991. 